\title{
Health of intraoral soft tissues in children with cerebral palsy and associated factors
}

\section{Serebral palsili çocuklarda intraoral yumuşak doku sağlığı ve ilişkili faktörler}

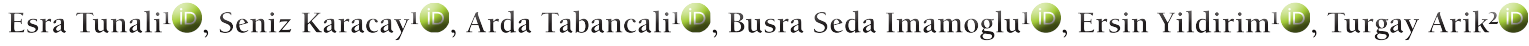 \\ ${ }^{1}$ Dept. of Orthodontics, University of Health Sciences, Hamidiye Faculty of Dental Medicine, Istanbul, Turkey, ${ }^{2}$ The Spastic \\ Children's Foundation of Turkey
}

\section{Abstract}

Background Cerebral palsy (CP) is a movement and posture disorder caused by damage to the immature brain. Oral health and functions are affected due to developmental disorders in the neuromuscular system of children with CP. The main ones are the hard and soft tissues in the mouth and chewing and swallowing functions.

Objective The aim of our study is to determine the condition of the oral soft tissues and associated factors in children diagnosed with CP in the growth and development period and to lead studies to prevent possible problems.

Methods Fifty-one children who receive service from Metin Sabancı units were included in the study. Diseases concomitant with CP, dietary habits, medications, and medical history forms, including the family status of the children were prepared. Physical examination of tonsillitis according to Brodsky Grading Scale, drooling with Balasco method, swallowing with clinical examination, gingival inflammation according to Modified Gingival Index (MGI) Classification, nutritional status and findings of reflux complaint were performed through face-toface interviews with parents.

Results $62.7 \%$ of children with CP included in our study were boys and $37.3 \%$ were girls. The mean age of the children was $9.63 \pm 2.40$ years. Nutritional disorders were found in $45 \%$ of the children, mouth breathing in $57 \%$ and gastroesophageal reflux disease in $19 \%$. The rate of children with CP with incorrect swallowing was $63 \%$ and the rate of those with drooling was $45 \%$. A significant relationship was found between drooling and incorrect swallowing. $45 \%$ of the examined children with CP use medication due to the complaint of epilepsy. In $12 \%$ of children, the tonsillar tissue covers $50-75 \%$ of the airway patency. In $78 \%$ of the children, the MGI value was

Corresponding author: Esra Tunali, Dept. of Orthodontics, Hamidiye Faculty of Dental Medicine, University of Health Sciences, Istanbul, Turkey. Phone: +90 532777 2570, E-mail: esrauclertunali@gmail.com

Received: 11 June 2021 Accepted: 25 June 2021

Conflict of Interest: None.

Funding: None

How to cite this article: Tunali E, Karacay S, Tabancali A, Imamoglu BS, Yildirim E, Arik T. Health of intraoral soft tissues in children with cerebral palsy and associated factors. Mucosa 2021;4:41-49

(c) (i) $($ This work is licensed under a Creative Commons Attribution-NonCommercial 4.0 International License. 
one and above and gingival enlargement was observed in $37 \%$.

Conclusion Providing effective oral hygiene in children with CP is important in terms of preventing gingival inflammation and enlargement. Interdisciplinary studies on mouth breathing, incorrect swallowing and drooling treatments are important. In order to improve oral health, it is necessary to examine the associated factors and administer treatments.

Key words: cerebral palsy, soft tissue, mouth mucosa, swallowing disorders, sialorrhea, mouth breathing

\section{O̊z}

Arka plan Serebral Palsi (SP) immatür beyindeki hasara bağlı oluşan hareket ve postür bozukluğudur. SP'li çocukların kas ve sinir sistemindeki gelişimsel bozukluklar sebebiyle ağız sağlı̆̆ı ve fonksiyonları etkilenmektedir. Bunların başlıcaları ağız içindeki sert ve yumuşak dokular ile çiğneme ve yutkunma fonksiyonlarıdır.

Amaç Çalışmamızın amacı büyüme ve gelişim dönemindeki SP tanısı almış çocuklarda ağız içi yumuşak dokuların durumunu ve ilişkili faktörleri tespit ederek, olası problemleri engellemeye yönelik çalışmalara öncülük etmektir.

Yöntem Çalışmaya Metin Sabancı birimlerinden hizmet alan 51 çocuk dahil edilmiştir. Çocukların SP'ye eşlik eden hastalıkları, beslenme alışkanlıkları, kullandıkları ilaçlar ve aile durumlarını içeren anamnez formları hazırlanmıştır. Tonsil muayenesi Brodsky Skalasına göre, salya akışı Balasco yöntemi ile, yutkunma klinik muayene ile, diş eti enflamasyonu Modifiye Gingival İndex (MGI) sistemine göre, beslenme durumları ve reflu şikayeti bulguları ebeveynlerle yüz yüze yapılan görüşmelerle gerçekleştirilmiştir.

Bulgular Çalışmamıza dahil edilen SP'li çocukların \%62.7s'i erkek, \%37.3'ü kızdır. Çocukların yaş ortalaması $9.63 \pm 2.40$ 'tür. Çocukların \%45'inde beslenme bozukluğu, \%57'sinde ağız solunumu, \%19'unda gastroözofagial reflü şikayeti tespit edilmiştir Hatalı yutkunma tespit edilen SP'li çocuk oranı \%63, ağız dışına salya akışı tespit edilenlerin oranı ise \%45'tir. Ağız dışına salya akışı ve hatalı yutkunma arasında anlamlı ilişki bulunmuştur. Muayene edilen SP'li çocukların \%45'i epilepsi şikayeti sebebiyle ilaç kullanmaktadır. Çocukların \%12'sinde tonsil dokusu havayolu açıklı̆̆ının \%50-75'ini kapatmaktadır. Çocukların \%78'inde MGI değeri 1 ve üzeridir, \%37'sinde dişeti büyümesi gözlenmiştir.

Sonuç SP'li çocuklarda etkin ă̆ız hijyeninin sağlanması dişeti enflamasyonu ve büyümesinin oluşmaması açısından önemlidir. Ağız solunumu, hatalı yutkunma, salya akışı tedavilerine yönelik interdispiliner çalışma önemlidir. Ağız sağlığının iyileştirilmesi için ilişkili faktörlerin de incelenerek tedavilerin yapılması gereklidir.

Anahtar kelimeler: serebral palsi, yumuşak doku, ağız mukozası, yutma bozuklukları, sialore, ağızdan soluma

\section{Introduction}

Cerebral Palsy (CP) is defined as a disease that occurs as a result of non-progressive damage to the immature brain and causes posture and movement disorder., ${ }^{1,2}$ There are very few studies on CP in Turkey. In these studies, the incidence of $C P$ was found to be 4.4 per 1000 live births and was reported as one of the most common causes of disability in early childhood. ${ }^{3,4}$ Studies have shown that $39.8 \%$ of pediatric patients with CP in Turkey have diplegic type, $28 \%$ hemiplegic type, $19.9 \%$ tetraplegic type, $5.9 \%$ ataxic type, and $6.4 \%$ dyskinetic type. ${ }^{3}$

Epilepsy, mental retardation, respiratory problems, motor function deficits, nutritional disorders, sleep problems, and oral and dental health problems are among the health problems associated with CP. About one-third of children with $\mathrm{CP}$ have chewing and swallowing problems. It is very difficult to provide oral care due to tone problems in orofacial muscles. For that reason, they have a high risk of developing oral and dental diseases. ${ }^{4,5}$

Gastroesophageal reflux (GER) is the most common esophageal disorder in children of all ages. ${ }^{6}$ In children with neurological disorders, GER has a higher incidence 
(15-75\%). Chronic dysphagia, loss of appetite, chronic irritability, crying, and more rarely dystonia in the face and neck region are observed in children with CP and GER. ${ }^{7}$ At the same time, a high rate of association between GER and dental erosion was found in these children. In a study, it was stated that GER is more common in children with quadriplegic $\mathrm{CP}$, and this condition increases the risk of disease in the mouth area with dental erosion. ${ }^{8}$

Motor and orofacial disorders also significantly affect the ability of children with $\mathrm{CP}$ to taste and chew their food. Especially children with advanced motor dysfunction have difficulty in eating hard foods. To improve the standard of oral health in children with $\mathrm{CP}$, it is important to understand the specific roles of sensory structures and functions of salivary glands in food consumption, together with motor function in orofacial structures. Perception deficits in sensory nerves of craniofacial tissues affect the sensory functions of children with $C P$. This effect limits the motor functions of the tongue, jaws, and orofacial muscles. ${ }^{9}$ Dysfunction in the muscles also affects the salivary glands, causing a decrease in saliva production, which provides a basic protection against tooth decay. ${ }^{10}$ In patients with $\mathrm{CP}$, saliva production can sometimes be a contributing factor in easier chewing and swallowing of food. Therefore, it should be noted that saliva production in CP patients is important, especially in those with more severe motor dysfunction. Active mouth breathing should be reduced to increase saliva production. ${ }^{9}$ Generally, food retention in the buccal and labial sulcus of the mouth in children with CP is due to weak muscles of mastication and poor brushing of these areas due to inadequate in-hand manipulation. ${ }^{11}$

In most children with $\mathrm{CP}$ who drool, the etiologic factor is not excessive production of saliva, but the inability to swallow saliva due to oromotor dysfunction. As a result of saliva flowing outside of the mouth; irritation, redness, and infection occur in the perioral region. ${ }^{12}$ This situation also reduces the child's adaptation to the social environment and causes psychological trauma for both children and their parents. ${ }^{13}$ Oromotor therapy recommended in children with $\mathrm{CP}$ is a treatment aimed at increasing the control of muscle functions in the orofacial region. ${ }^{14}$ Various tongue, lip and cheek exercises are performed to reduce saliva flow outside of the mouth. ${ }^{15}$

The aim of this study is to determine the conditions of the oral soft tissues and associated factors in children diagnosed with $\mathrm{CP}$ in the growth and development period, and to make suggestions to prevent possible problems.

\section{Methods}

The Spastic Children's Foundation of Turkey (SCFT), which is part of the Sabanc1 Foundation is the only center in Turkey that specifically provides interdisciplinary rehabilitation support to children with CP. For that reason, the research was carried out in this center. After the subject was determined, the details of the study were determined by meeting with the physiotherapist, speech therapist, osteopath and family counselors working with children with CP under SCFT. The research team was informed about the methods of cooperation with children with $\mathrm{CP}$ by the center. Ethics committee approval was obtained from the Hamidiye Scientific Research Ethics Committee of the University of Health Sciences (05.06.2020, 19/163) and research permission was obtained from the the Academic Committee of the Spastic Children's Foundation of Turkey. According to the result of the power analysis made by taking the strength of the study as $95 \%$ and the margin of error $\alpha=0.05$, the number of people who would participate in the study was determined as at least 45 . The study included 51 children in the 6-14 age group diagnosed with CP, who benefited from the service units at Metin Sabanci Center affiliated to SCFT. Informed consent forms were obtained from all parents by explaining the content of the study. Briefings and examinations were performed face to face and sterile examination kits were used. Medical history forms containing personal and sociodemographic information (age, sex, diseases concomitant $\mathrm{CP}$, types of $\mathrm{CP}$, dietary habits, medications, etc.) were prepared. 
Physical examination of tonsillitis was performed according to Brodsky Scale when the patients were in sitting position. ${ }^{16}$ Saliva flow was checked in the resting position without stimuli. Mild drooling was analyzed using the Balasco method, according to which saliva was detected to drop onto the vermilion border of the lips, moderate drooling onto the chin, and severe drooling onto clothes. ${ }^{17}$ The swallowing pattern was evaluated by occlusion of posterior teeth during swallowing, control of temporal and masseter muscle contraction with fingertips, and other clinical observations. ${ }^{18}$ Gingival inflammation examination was performed using the Modified Gingival Index evaluation system. ${ }^{19}$ Reflux complaints and nutritional status were evaluated through face-toface interviews with parents. Gingival enlargement was graded according to McGaw et al. ${ }^{20}$ classification system.

\section{Results}

$62.7 \%(n=32)$ of children with CP included in our study were boys and $37.3 \%(n=19)$ were girls. The mean age of the children was $9.63 \pm 2.40$ years. The most common type of $\mathrm{CP}$ in children with $\mathrm{CP}$ is spastic CP with a rate of $74.5 \%$ (Table 1 ).

Nutritional disorders were detected in $45 \%(n=29)$ of the children (Table 2) and one child was fed with percutaneous endoscopic gastrostomy. Among the factors that cause these disorders in children with

Table 1. Distribution by gender and CP type

\begin{tabular}{llccc}
\hline \multirow{3}{*}{ Gender } & & $\mathrm{n}$ & $\%$ \\
& Boy & 32 & 62.7 \\
& Girl & 19 & 37.3 \\
\hline \multirow{4}{*}{ Type of CP } & Ataxic & 3 & 5.9 \\
& Dyskinetic & 5 & 9.8 \\
& Mix & 5 & 9.8 \\
& Spastic & 38 & 74.5 \\
\hline Total & & 51 & 100 \\
\hline
\end{tabular}

CP, Cerebral palsy nutritional disorders, there are mainly chewing and swallowing problems. There are two or more types of nutritional disorders in eight children.

While mouth breathing was detected in $57 \%(n=29)$ of children with $\mathrm{CP}$, nasal breathing was observed in $43 \%(n=22)$.

GER complaints were detected in $19 \%(n=10)$ of children with CP.

$45 \%(n=23)$ of children with CP have varying degrees of drooling outside of the mouth. The rate of children with $\mathrm{CP}$ who were found to have incorrect swallowing (simple tongue thrust, physiologic tongue thrust, and complex tongue thrust) was $63 \%(n=32)$. Incorrect swallowing was present in $91.3 \%$ of children with drooling outside of the mouth, and macroglassia was detected in four children with CP. A statistically significant difference was found between swallowing and the level of drooling outside of the mouth $(P<0.05)$. In infantile swallowing, severe drooling was found in the first place and moderate salivary flow was found in the second rank. In the complex tongue thrust, on the other hand, drooling was found at the highest level. A higher rate of mild drooling was detected in patients with simple tongue thrust. In patients with adult swallowing patterns, no drooling was observed, or a low level of drooling was observed (Table 3).

$53 \%$ of the examined children with $\mathrm{CP}$ use regular

Table 2. Distribution by type of malnutrition

\begin{tabular}{|c|c|c|c|}
\hline & & n & $\%$ \\
\hline \multirow{4}{*}{$\begin{array}{l}\text { Type of } \\
\text { malnutrition }\end{array}$} & $\begin{array}{l}\text { Inability to finish } \\
\text { the meal }\end{array}$ & 10 & 34 \\
\hline & $\begin{array}{l}\text { Difficulty } \\
\text { swallowing food }\end{array}$ & 8 & 28 \\
\hline & $\begin{array}{l}\text { Vomiting after a } \\
\text { meal }\end{array}$ & 4 & 14 \\
\hline & $\begin{array}{l}\text { Eating time longer } \\
\text { than } 45 \text { minutes }\end{array}$ & 7 & 24 \\
\hline Total & & 29 & 100 \\
\hline
\end{tabular}


Table 3. Distribution according to the relationship between swallowing pattern and drooling level

\begin{tabular}{|c|c|c|c|c|c|c|c|c|c|}
\hline & \multicolumn{2}{|c|}{ Mild } & \multicolumn{2}{|c|}{ Moderate } & \multicolumn{2}{|c|}{ Severe } & \multicolumn{2}{|c|}{ None } & \multirow[b]{2}{*}{$\boldsymbol{P}$} \\
\hline & $\mathbf{n}$ & $\%$ & $\mathbf{n}$ & $\%$ & $\mathbf{n}$ & $\%$ & $\mathbf{n}$ & $\%$ & \\
\hline $\begin{array}{l}\text { Simple tongue } \\
\text { thrust }\end{array}$ & 1 & 33.3 & 3 & 27.3 & 2 & 22.2 & 6 & 21.4 & \\
\hline Adult swallow & 2 & 66.7 & 0 & 0.0 & 0 & 0.0 & 17 & 60.7 & \\
\hline Infantile & 0 & 0.0 & 5 & 45.4 & 6 & 66.7 & 4 & 14.3 & $<0,001$ \\
\hline $\begin{array}{l}\text { Complex tongue } \\
\text { thrust }\end{array}$ & 0 & 0.0 & 3 & 27.3 & 1 & 11.1 & 1 & 3.6 & \\
\hline Total & 3 & 100 & 11 & 100 & 9 & 100 & 29 & 100 & \\
\hline
\end{tabular}

medication (Table 4). The most common reason for using medications is epilepsy $(45 \% ; n=23)$, while other reasons for using medications are autism, thyroid and neurological disorders.

Table 4. Distribution by medication use

\begin{tabular}{lllll}
\hline & & n & $\%$ \\
\multirow{2}{*}{ Medication use } & Yes & 27 & 53 \\
\cline { 2 - 4 } & No & 24 & 47 \\
\cline { 2 - 4 } & Total & 51 & 100 \\
\hline \multirow{2}{*}{$\begin{array}{l}\text { Reason for using } \\
\text { medication }\end{array}$} & Epilepsy & 23 & 85 \\
\cline { 2 - 4 } & Other & 4 & 15 \\
\cline { 2 - 4 } & Total & 27 & 100 \\
\hline
\end{tabular}

In $12 \%(n=6)$ of children with $C P$, the tonsillar tissue covers $50-75 \%$ of the airway patency. In 45 children with $\mathrm{CP}$, it was determined that the tonsillar tissue was not large enough to affect the airway patency (Table 5).

No signs of gingival enlargement were observed in 32 children with CP (Table 6). 17 of 30 children without gingival enlargement (Grade 0) are using medication due to epilepsy. Seven of these children brush their teeth regularly and 10 of them do not brush their teeth regularly. Growth limited to the gingival margin (Grade 1) was detected in 12 children with CP. Seven of the children with Grade 1 gingival enlargement use medication due to epilepsy complaint, three of

Table 5. Distribution by tonsil size

\begin{tabular}{lcc}
\hline & n & $\%$ \\
Grade 0 & 45 & 88 \\
Grade 3+ & 6 & 12 \\
\hline Total & 51 & 100 \\
\hline
\end{tabular}

these children brush their teeth regularly and four of them do not brush their teeth regularly. Gingival enlargement covering the interdental papilla and marginal gingiva (Grade 2) was detected in seven children with CP. Three of the children with Grade 2 gingival enlargement use medication due to the complaint of epilepsy. Two of these children brush their teeth regularly and one of them does not brush their teeth regularly. Gingival enlargement covering $2 / 3$ or more of the gingival crown (Grade 3) was not found in any of the children with $\mathrm{CP}$. 
Healthy gingiva was found in $22 \%$ of children with CP, mild inflammation, discoloration and edema in a part of the gingiva were found in 33\%. Mild inflammation in all regions of the gingiva was observed in $35 \%$ of the children, and moderate inflammation, red and edematous gingiva were observed in $10 \%$ of the children. Severe inflammation, marked redness of the gingiva, edema, and spontaneous gingival hemorrhage were not observed in any of the children (Table 6).

Table 6. Distribution by gingival enlargement and modified gingival index

\begin{tabular}{l|ccc}
\hline & Grade 0 & 32 & 63 \\
\hline $\begin{array}{l}\text { Distribution } \\
\text { by gingival } \\
\text { enlargement }\end{array}$ & Grade 1 & 12 & 23 \\
\hline & Grade 2 & 7 & 14 \\
\hline $\begin{array}{l}\text { Grade 3 } \\
\text { Total }\end{array}$ & 0 & 0 \\
\hline $\begin{array}{l}\text { Mistribution of } \\
\text { modified gingival }\end{array}$ & MGI 0 & 11 & 22 \\
\hline MGI 1 & 17 & 33 \\
\hline & MGI 3 & 18 & 35 \\
\hline & MGI 4 & 0 & 10 \\
\hline
\end{tabular}

\section{Discussion}

In our study, since the patients were children with special needs, MGI measurement system was used to detect gingival inflammation. In this evaluation system, problems such as bleeding and pain do not occur, since probing is not performed on the gingiva. At the same time, studies have shown that MGI is as sensitive as the Gingival Index system, which measures by probing, in detecting gingival inflammation. ${ }^{21}$ Periodontal problems are frequently observed in patients with CP due to the inability to provide effective oral hygiene and the side effects of the medicines used. ${ }^{22}$
In a study conducted on 105 children aged 14 and 15 with CP, the Gingival Index scores were found to be higher than the healthy children in the control group. It has been observed that the Gingival Index scores of the children who need help from their parents especially during tooth brushing. ${ }^{23}$ In a different study conducted by Nouf et al. ${ }^{24}$ on children with $\mathrm{CP}$, it was stated that Gingival Index scores increase with age, and the reason for this might be Puberty Gingivitis, similar to normal children. Similarly, in our study, it was found that $78 \%$ of children with CP did not have healthy gums, and $31 \%$ had gingival enlargement. It has been observed that gingival enlargement is not only related to the medications used for epilepsy, but also due to inadequate oral hygiene of the patient. In addition to inadequate oral hygiene, many factors such as medications, mouth breathing, and nutritional deficiencies affect gingival inflammation. Since gingival inflammation is seen more frequently and more severely in children with CP than in healthy children, it is important to provide oral health education with their parents, to carry out this education in practice, to eliminate other predisposing factors, and to carry out frequent follow-ups and controls.

High incidence of GER in children with $C P$ has been reported..$^{25}$ In a study conducted by Guare et al. ${ }^{26}$, $43.5 \%$ of GER was detected in children aged 3-13 years. In a study conducted by Giudice et al. ${ }^{27}$ in children with CP between the ages of 6 months and 12 years, the rate of GER was found to be $92 \%$. The rate of GER in children with CP in our study was $10 \%$. It is thought that the reason for these different results in studies may be due to the different age ranges of children with $C P$, the higher rate of GER at earlier ages, or the differences in body parts affected by $\mathrm{CP}$ among children. If dental erosions are observed in this group of patients, they should be referred to a gastroenterologist, and periodic examinations should be provided, and consumption of acidic beverages should be completely stopped for the health of soft tissues in the mouth. ${ }^{9}$

Rieken et al. ${ }^{28}$, stated that the reason for the 
underweight of children with CP compared to healthy children in the similar age group is not due to the high basal metabolic rates, but insufficient weight gain. Irregular drug use, discontinuation of drugs, nutrition of children with low-calorie foods, not spending enough time to feed the disabled child, increased calorie needs in the acute period of the disease, or stopping of oral nutrition due to hospitalization are among the possible causes of insufficient weight gain. ${ }^{29}$ In our study, nutritional disorders were detected in $45 \% \quad(n=29)$ of children with CP. Complaints include inability to swallow food, vomiting after eating, prolonged eating time, and inability to finish the meal. At the same time, the high rate of incorrect swallowing (63\%) shows the importance of exercise and the use of appliances for correct swallowing habits in these children.

While drooling is considered normal in infants and young children, the continuation of this condition after the age of four is considered pathological. The salivary flow rate in children with $\mathrm{CP}$ ranges from $10 \%$ to $58 \%{ }^{12,30}$ Due to this high saliva flow, the fact that the mouth area has to be wiped constantly causes irritation of this area, infection and at the same time, the isolation of children from social environments. ${ }^{12}$ In our study, drooling was detected in $45 \% \quad(n=23)$ of children with CP. In these children, the Innsbruck sensorimotor activator and regulator (ISMAR), Castillo Morales and Hinz appliance ${ }^{31}$, tongue and lip exercises, oral motor therapy (OMAR) are the tools used to regulate saliva flow and gain correct swallowing habits. It is thought that starting the use of appliances and the tongue-lip exercises aimed at controlling the saliva flow of children at an early age of growth and development will provide an advantage in both the exercise of the oral region muscles and the adaptation of the patients to these appliances.

In the study conducted by Garde et al. ${ }^{32}$ on 832 healthy children aged 6-12 years, the rate of mouth breathing was $4.3 \%$, while the rate of incorrect swallowing was $4.9 \%$. In studies on patients with CP, it has been found that mouth and facial structure disorders associated with incorrect tongue position, weak swallowing reflex, mouth breathing and orofacial muscle incoordination resulting from these reasons are high. ${ }^{33}$ In our study, it was determined that the rate of mouth breathing in children with CP was $57 \%$, and the rate of incorrect swallowing was $63 \%$. It is important to determine the main factor that causes mouth breathing in children with $\mathrm{CP}$. After the medical general evaluation, patients with mouth breathing after eliminating factors such as oral motor disorders, tonsillar hypertrophy, polyps, nasal septum deviation should work together with speech and language therapists, and respiratory physiotherapists.

Causes of mouth breathing in young children include allergic rhinitis and adenotonsillar hypertrophy, which cause mechanical obstruction of airflow. ${ }^{34}$ Sakalli et al. ${ }^{35}$ found that children with adenoid hypertrophy had higher levels of mouth breathing, drooling during sleep, and sleep disorders than children who had undergone adenotonsillectomy. In our study, adenoid hypertrophy was detected in five children with $\mathrm{CP}$, and mouth breathing was observed in only three of these children. Adenoid hypertrophy was not detected in 26 children with mouth breathing. GER was evaluated only according to patient complaints and findings of intraoral erosion. The lack of a more detailed evaluation is one of the limitations of our study. Detailed investigation of the factors that cause mouth breathing in these children, elimination of the factor, correction of faulty breathing are important for the health of the hard and soft tissues in the mouth and face structure of children with $\mathrm{CP}$ and to increase the quality of life of children.

In conclusion, it is possible for these children to improve physically and mentally if the problems and needs of patients with CP are determined at an early age and treated on time. Realistic positive results can be achieved with long-term rehabilitation and correct guidance. A successful rehabilitation program can be carried out with the interdisciplinary work of a team of an orthopedist, a pediatric neurologist, a child psychiatrist, a physiotherapist, a clinical psychologist, an occupational therapist, a speech therapist, a 
social service specialist, and an orthotics technician, together with the patient and his/her family. ${ }^{36}$ While forming the team, it is important to include dentists experienced in the oral health of children with special needs.

\section{Ethics committee approval:}

Local Ethics Committee approval was obtained (05.06.2020, 19/163)

Informed consents: They were obtained.

Peer-review: Externally peer-reviewed.

Authorship contributions:

Conception and design, or analysis and interpretation of data: ET, SK, AT, BSI, TA

Drafting the manuscript or revising the content: ET, SK, EY, TA

Final approval of the version to be published: ET, SK, EY, TA

\section{References}

1. Bax M, Goldstein M, Rosenbaum P, et al. Proposed definition and classification of cerebral palsy. Dev Med Child Neurol 2005;47:571.

2. Cans C, Dolk H, Platt MJ, et al. Recommendations from the SCPE collaborative group for defining and classifying cerebral palsy. Dev Med Child Neurol 2007;49:35-8.

3. Serdaroglu A, Cansu A, Ozkan S, Tezcan S. Prevalence of cerebral palsy in Turkish children between the ages of 2 and 16 years. Dev Med Child Neurol 2006;48:413-6.

4. Cans KM, Cans C. Cerebral palsy update. Brain Dev 2009;31:537-44.

5. McIntyre S, Taitz D, Keogh J, Goldsmith S, Badawi $\mathrm{N}$, Blair E. A systematic review of risk factors for cerebral palsy in children born at term in developed countries. Dev Med Child Neurol 2013;55:499508.

6. Winter S, Autry A, Boyle C, Allsopp MY. Trends in the prevalence of cerebral palsy in a population based study. Pediatrics 2002;110:1220-5.

7. Sullivan PB. Gastrointestinal disorders in children with neurodevelopmental disabilities.Dev Disabil Res Rev 2008;14:128-36.

8. Henderson CM, Rosasco M, Robinson LM, et al.
Functional impairment severity is associated with health status among older persons with intellectual disability and cerebral palsy. J Intellect Disabil Res 2009;53:887-97.

9. Akhter R, Hassan NMM, Martin EF, Nadkarni M, Khandaker G. Oral health in children with cerebral palsy. In Cerebral Palsy Clinical and Therapeutic Aspects (Isam Jaber Al-Zwaini, eds.) Intech Open, 2018;79-92.

10. Lamkin MS, Oppenheim FG. Structural features of salivary function. Crit Rev Oral Biol Med 1993;4:251-9.

11. Sheetal A, Hiremanth VK, Patil AG, Sajjansetty S, Kumar SR. Malnutrition and its oral outcome - a review. J Clin Diagn Res 2013;7:178-80.

12. Dougherty NJ. A review of cerebral palsy for the oral health professional. Dent Clin North Am 2009;53:329-38.

13. Camargo FD, Aparecida M, Frias AC, Antunes JLF. The incidence of dental caries in children and adolescents who have cerebral palsy and are participating in a dental program in Brazil. Spec Care Dentist 2011;31:210-5.

14. Lee ASY, Gibbon FE. Non-speech oral motor treatment for children with developmental speech sound disorders. Cochrane Database Syst Rev 2015;3:380-92.

15. Kublay S. Nörogelişimsel bozukluğu olan çocuklarda oral motor terapi sonuçları. Abant İzzet Baysal Üniversitesi İzzet Baysal Tıp Fakültesi 2007.

16. Brodsky L. Modern assessment of tonsils and adenoids. Pediatr Clin North Am 1989;36:1551-69.

17. Blasco PA, Allaire JH. Drooling in the developmentally disabled: management practices and recommendations. Dev Med Child Neurol 1992;34:849-62.

18. Rosenbaum CH, Mcdonald RE, Levitt EE. Occlusion of cerebral-palsied children. J Dent Res 1966;45:1696-700.

19. Lobene RR, Weatherford T, Ross NM, Lamm RA, Menaker LA. Modified gingival index for use in clinical trials. Clin Prev Dent 1986;8:3-6.

20. McGaw T, Lam S, Coates J. Cyclosporin induced gingival overgrowth: correlation with dental plaque scores, gingivitis scores, and cyclosporin levels in serum and saliva. Oral Surg Oral Med Oral Pathol 1987;64:293-7.

21. Lobene RR, Mankodi SM, Ciancio SG, et 
al. Correlations among gingival indices: a methodology study. J Periodontol 1989;60:159-62.

22. Mani SA, Mote N, Kathariya M, Pawar KD. Adaptation and development of dental procedure in cerebral palsy. Pravara Med Rev 2015;7:17-22.

23. Nielsen AL. Plaque and gingivitis in children with cerebral palsy: relation to $\mathrm{CP}$ diagnosis, mental and motor handicap. Tandlaegernes Tidsskr 1990;5:316-20.

24. Alhammad NS, Wyne AH. Plaque and gingival health status among cerebral palsied children of Riyadh city. Pakistan Oral \& Dental Journal 2011;31:116-9.

25. Erasmus CE, van Hulst K, Rotteveel JJ, et al. Clinical practice: swallowing problems in cerebral palsy. Eur J Pediatr 2012;171:409-14.

26. Guare RO, Ferreira MC, Leite MF, et al. Dental erosion and salivary flow rate in cerebral palsy individuals with gastroesophageal reflux. J Oral Pathol Med 2012;41:367-71.

27. Giudice ED, Staiano A, Capano G, et al. Gastrointestinal manifestations in children with cerebral palsy. Brain Dev 1999;21:307-11.

28. Rieken R, van Goudoever JB, Schierbeek H, et al. Measuring body composition and energy expenditure in children with severe neurologic impairment and intellectual disability. Am J Clin Nutr 2011;94:759-66.

29. Asgarshirazi M, Soltani MF, Keihanidost Z, Shariat M. Evaluation of feeding disorders including gastro esophageal reflux and oropharyngeal dysfunction in children with cerebral palsy. J Family Reprod Health 2017;11:197-201.

30. Tahmassebi JF, Curzon MEJ. Prevalence of drooling in children with cerebral palsy attending special schools. Dev Med Child Neurol 2003;45:613-7.

31. Kirzioglu Z, Bayraktar C. Serebral palsili çocuklarda sık rastlanan oral problemler, ağız dışına salya akışı ve tedavi önerileri. SDÜ Sağlık Bilimleri Dergisi 2018;156-62.

32. Garde JB, Suryavanshi RK, Jawale BA, et al. An epidemiological study to know the prevalence of deleterious oral habits among 6 to 12 year old children. J Int Oral Health 2014;6:39-43.

33. Andersen GL, Irgens LM, Haagaas I, Skranes JS, Meberg AE, Vik T. Cerebral palsy in Norway: prevalence, subtypes and severity. Eur J Paediatr Neurol 2008;12:4-13.
34. Liral ALS, IzquierdoI AM, Prado S, et al. Adenoid hypertrophy and open bite. Braz J Oral Sci 2011;10:1721.

35. İnönü-Sakallı N, Sakallı C, Tosun Ö, AkşitBıçak D. Comparative evaluation of the effects of adenotonsillar hypertrophy on oral health in children. Biomed Res Int 2021;2021:5550267.

36. Bhowate R, Dubey A. Dentofacial changes and oral health status in mentally challenged children. J Indian Soc Pedod Prev Dent 2005;23:71-3. 